\title{
DISINTEGRATION OF MONETRY SYSTEM OF MEDIEVAL SERBIA
}

\begin{abstract}
The subject matter of this paper is the process of gradual disintegration of monetary system of medieval Serbia during the second half of the $14^{\text {th }}$ and the first half of the $15^{\text {th }}$ century. This period is characterized by an appearance of frequent usurpations of the ruling right to mint coinage by local landlords and the attempts of the rulers from Lazarević and Branković families to restore unified monetary system. Common debasements and restorations of silver coinage provoked economic instability and induced frequent turning backwards to the custom of using weighted silver instead of silver coins as commodity monetary standard. The aim of this paper is to explain the reasons for those phenomena. We apply qualitative, historical, empirical analysis where we consider money minting right holders and their decisions to debase and restore the value of silver dinars. We found that gradual disintegration of monetary system of medieval Serbian State continued until the fall of Serbian Despotate as a consequence of political instability following dissolution of medieval Serbian Empire and economic and financial exhaustion of Serbia by Ottoman suzerains.
\end{abstract}

Key words: the right to mint coinage, commodity monetary standards, silver dinar debasements and restorations, Serbian Despotate, Ottoman Suzerainty

\section{Introduction}

Serbian medieval monetary system was the silver monometallic one. Starting from the 1270s, Serbian medieval state ruled by the Nemanjić dynasty regularly used domestic sources of silver ore to mint silver dinars. The basic metal was silver and copper was an auxiliary one. Minting standards of silver dinar were originally established after the Venetian silver grosso weighing 2,178 grams and having silver quality of 0.965 . All payments in Serbia were actually made in silver dinars but they were calculated in perpera, named after Byzantine golden yperpiron ( $v \pi \varepsilon \rho \pi v \rho \circ v$ ) that was in circulation until the beginning of $14^{\text {th }}$ century. Perpera was a fictitious accounting monetary unit of 12 dinars. Perpera was used as it was necessary to establish a permanent ratio between the silver dinar

Professor Dragana Gnjatović, PhD, Faculty of Hotel Management and Tourism, University of Kragujevac, e-mail: dragana.gnjatovic@yahoo.com 
and a certain quantity of gold in a monetary system where golden coins were not minted. ${ }^{1}$ All the calculations were still done in perperas even when in the 1330s Serbian medieval dinar lost a quarter of its value and weighed on average 1.70 grams. This custom remained also during the reign of both Tsar Dušan (1331-1355)., who minted dinars weighing up to 1.50 grams, and his son Tsar Uroš (1335-1371) whose most valuable dinars weighed 1.20 grams (D. Gnjatović, 1998, pp. 94-130). Imperial mints were situated in mining centres and urban imperial strongholds. Tsar Dušan's mints that were related to the mining centres operated on the Mountain Rudnik and in Novo Brdo, and those related to urban strongholds were situated in Trepča, Prizren, Skopje and Ohrid. Further, autonomous towns of Kotor and Ulcinj used to mint money on behalf of Tsar Dušan.

Rulers from the Nemanjić dynasty had been in exclusive right to mint coinage in medieval Serbia up till the death of Tsar Dušan. Perceived as an expression of the state sovereignty, this right was regarded as a grand, regal, non-material right pertaining to rulers. The ruler was the only one empowered to pass a piece of legislation by which national currency minting was regulated: to establish which precious metal the money was to be minted from, to ascertain the alloy structure of the primary and secondary metal, along with the number of silver dinars to be struck from one litra of pure silver. The first Serbian minting law, dating back from 1354, stipulates that silver dinars ought to be minted exclusively in those mints licensed by the Tsar. ${ }^{2}$ Given that money minting was seen as a ruler sovereignty feature, money forgery was perceived as an attack on the ruler, that is, the state itself. Therefore, the Tsar Dušan's Code of Laws envisaged draconic penal measures for money forging. ${ }^{3}$

It was in the mid-14 ${ }^{\text {th }}$ century and accompanied by the general loss of power of that far centralised state authorities that Serbian medieval monetary system started falling apart. The process of fast decreasing in power of the centralised authority in Serbian medieval state is invariably linked to the sudden and to the day unexplained death of Tsar Dušan in 1355. Serbian Empire was at the peak of its power at the time. It encompassed the territories of today's Serbia, Montenegro, Macedonia, parts of Greece and Albania. Inland, it bordered Bosnia, Hungary, Wallachia, Bulgaria, Byzantine Empire and the Dukedom of Athens, whilst at sea it bordered the Venetian Republic. Serbian empire's economic strength laid in the abundance of precious metal ores, especially silver. Serbia supplied Venetian and other Italian mints with silver through Dubrovnik.

To read more on the origin of fictitious perpera in medieval Serbia as an accounting monetary unit see (D. Gnjatovic, 1998, pp. 37-48)

2 Articles 168, 169 and 170 of the Tsar Dusan's Code of Laws, adopted at the Serez synod in 1354 (S. Novaković, 1898, p. 169)

3 Tsar Dusan's Code of Laws stipulated death penalty in the form of burning at the stake as a punishment for forging of silver dinars. (D. Gnjatović, 2000, pp. 107-128) 
After the death of Tsar Dušan, Serbian Empire started stumbling under the burden of clashes of interests amongst individual local feudal rulers. At that time the Ottomans had already started their war campaigns in the Balkans with a view to expanding their young state and increasing their sources of income. ${ }^{4}$ Their military advances in Europe in the second half of the $14^{\text {th }}$ century were aided by the fact that they concurred with the political dissolution of not only Serbian Empire but also Byzantine and Bulgarian Empire. Whilst local Balkan feudal rulers were losing their strength in mutual clashes and skirmishes, thereby taking their respective states into chaos and dissolution, the Ottomans were quickly gaining ground in the Balkans with the considerable help from their strong centralised authorities and disciplined armed forces.

\section{The usurpation of money minting right}

Rulers from the Nemanjić dynasty perceived the money minting right as their private right that they could partly relinquish at their will. Thus, Tsar Dušan himself limited his monetary sovereignty by means of conceding his money minting right in the north of Macedonia to a powerful feudalist John Oliver (orig. Jovan Oliver). ${ }^{5}$ In this case we cannot talk about the usurpation of the right to mint coinage as John Oliver did not lay claim to that right at his own will. This case was all about the limitation of the imperial monetary sovereignty as opposed to the money minting right usurpation, which is corroborated by the fact that despot Oliver's money had his name and title inscribed on one side of the coin and the Tsar's on the other.

However, during the reign of Dušan's son Uroš, ruler's right to mint coinage in Serbian medieval state was usurped on various occasions. The usurpation was preceded by the loss of a part of the state territory. At the very beginning of his reign, Uroš fought with Ottomans and lost in the south a part of Thessalia and Epirus, whilst in the north, in the Danube basin, he lost the region of Braničevo that fell into the hands of the Hungarian king Ludovic I. Thus reduced state territory and weakened Empire created favourable conditions for powerful feudal lords to thrive. Consequently, they started usurping various ruling rights, money minting right being one of them. It has been proven beyond any doubt that this right was then usurped by Tsar Dušan's widow, Tsarina Jelena, as well as the following feudal rulers: despot Uglješa, king Vukašin, queen Jelena, Nikola

The foundations of the Ottoman Empire were set around 1300 in the northern part of Asia Minor by the chieftain of Turan tribes, Osman, who had just freed himself from the vassal position in relation to Ali-Edin, the sultan of the Seljuqs. S. Novaković, 1933, p. 23).

5 John Oliver was one of the most powerful feudal lords during the reign of the King and Tsar Dusan. After the Empire was announced in 1436, the Tsar bestowed upon him Northern Macedonia and the title of despot for his extraordinary meritorious service. (J. Radonić, 1914, pp. 74-108)

Vol. 11, No 4, 2014: 129-144 
Altomanović and Djuradj Balsić I (V. Ivanišević, 2001, p. 110). The king Vukašin family minted money in Prizren and Nikola Altomanović operated the same business on the Mountain Rudnik as from 1367. After the death of king Vukašin in 1372 the Prizren mint was grabbed by Djuradj Balšić I and after the defeat of Nikola Altomanović in 1373 the Rudnik mint fell for the first time into the hands of Prince Lazar (S. Stojaković, 2006, p. 127). They all minted the silver dinars employing the same minting standards as Tsar Uroš.

When Uroš succeeded his father Tsar Dušan as a ruler the so called imperial dinars were in circulation, weighing on average 1.50 grams. Owing to their quality and weight sustainability these imperial dinars were used as a means of payment even outside the borders of Serbia. ${ }^{6}$ However, Uroš opted for the debasement of silver dinars. The same as Tsar Uroš dinars, feudal lords' coinage also constantly lost its weight. Tsar Uroš' first silver coins weighed 1.20 grams and his last ones weighed only 0.64 grams, whilst during his reign the average weight of silver coins minted by the mentioned feudal lords dropped from 1.20 grams to 0.51 grams (V. Ivanišević, 2001, 152).

\section{Autonomous monetary rights under the Ottoman suzerainty}

After the battle on Marica river in 1371 the majority of Balkan feudalists, including Serbian local feudal lords, became vassals to sultan Murad I (13621389). Vassals were obliged to pay the annual tribute as a sign of their subjection to Islamic state and also to send auxiliary forces to aid the sultan's war campaigns. Sultan's vassals became Byzantine and Bulgarian tsars, many Greek feudalists, as well as Serbian feudal lords king Marko, Jovan and Konstantin Dragaš and some other Serbian princes in Macedonia. After Prince Lazar got killed in the battle of Kosovo in 1389 the same fate befell his successors too. Further, Vuk Branković became sultan Bayazit I's (1389-1402) vassal when in 1392 the sultan took Skopje away from him. At the same time the sultan's vassals in Zeta also became Djuradj Stracimirović II followed by his successor Balša II. Also, the majority of the Albanian rulers accepted to pay tribute to the sultan at the end of the $14^{\text {th }}$ century and the same practice was adopted in the first half of the 15th century by Bosnia and across the Danube states Moldavia and Walachia (M. Spremić, 1970, pp. 9-59).

Unless vassals properly and timely fulfilled their obligations towards the sultan their states would be proclaimed "war abodes" and consequently subject to ruthless destruction (H. Inaldzik, 1974, p. 18). However, until the Ottomans in the end conquered a region, obedient vassals who regularly met their obligations towards the sultan enjoyed an internal, regional autonomy. It was a rule

Dušan's denarii del imperador, are mentioned in Dubrovnik's written memorials dating from 1353 and 1354 (S. Dimitrijević, 1959). 
that a vassal's first successor should become a vassal too but with a proviso that he agreed to pay some new and heavier duties to the sultan. These duties would in time exhaust citizens and their region economically and, consequently the region would, thus economically weakened, become an arena of the Ottoman final conquers (M. Spremić, 1970, pp. 47-52).

Autonomy of the sultan's vassals in the European part of the empire referred to the exploitation of silver mines and money minting. Out of these forms of his Balkan and across-the-Danube vassals' autonomy the sultan reaped enormous immediate material benefit of tributary character. The vassals would retain their monetary autonomy for as long as sultan found it profitable, upon which all the mines and mints would fall into the Ottoman hands. Monetary autonomy encompassed national money minting conducted in line with either existing customs or written rules which vassals would lay down by themselves. When the Ottoman rule in the Balkans was definitely established in the first half of the $15^{\text {th }}$ century vassals started losing their monetary autonomy one after another. Amongst European vassal countries only Wallachia and Moldova retained their autonomy. Namely, the Ottomans failed to conquer these across-the-Danube states that remained in vassal position up until the $19^{\text {th }}$ century (M. Maxim, 1998, pp. 69-88).

The defeat of the Christian army who lost to the Ottomans in the battle on the Marica in 1371, followed the same year by the death of the last ruler from the Nemanjić dynasty, tsar Uroš, marked the end of a centralised government in medieval Serbia. The dissolution of the state led to the dissolution of its monetary system too. Money minting no longer existed on the central government level as there was no longer such government in the first place. Some princes became regional rulers and primarily for fiscal reasons they started minting money independently. Thus, due to the dissolution of the state, money minting in Serbia lost its characteristics of iura regalia. Monetary sovereignty that used to belong to the ruler, that is, to the state, was replaced by a string of regional rulers' monetary autonomies. Each of their monetary autonomies reached exclusively to the "borders" of their respective autonomous regions that they effectively ruled. Still, as in a political sense, borders of the autonomous regions changed rapidly, the monetary autonomy was a very unstable category in the territorial sense. Apart from regional rulers some towns such as Prizren and Skopje also started to mint money.

If the territorial principle of monetary autonomy is regarded in a very broad and conditional way, Serbian regional rulers' monetary system in the period between 1371 and 1402 can be divided in four categories (V. Ivanišević, 2001, p. 147). The first group comprises all the mints in Macedonian region where minting was conducted by king Marko, county ruler Gropa, regional ruler Andraš, as well as Jovan and Konstantin Dragaš. The second group includes mints of Nikola Altomanović, Prince Lazar and Duke Stefan Lazarević, who ruled central and north regions of Serbian state. Vuk Branković' mints make up the third cate- 
gory, including regional rulers subject to him in the regions of Sjenica, Mountain Kopaonik, centres in Trepča and Priština, as well as mints in Skopje and Prizren. The last, separate group includes the mints of the Balšic family who ruled in the Zeta region, Drač and Skadar. Regional rulers' money circulated mainly in Serbia, and predominantly in those regions where it was minted.

In a constant strife over sources of income vassals would be snatching from each other the right to exploit mines and mints, until, in the end, these same mints and mines ended up in the Ottoman hands. Political skirmishes amongst Serbian regional rulers, which always preceded final Ottoman conquers, directly affected frequent shifts in monetary autonomy holders in some regions under the sultan's suzerainty. The Ottomans made use of these clashes as they facilitated their easier and quicker usurpation of mines and mints. A telling example illustrating this is the Priština mint exploitation. Though he pledged to obedience to the sultan Bayazit I by means of paying him a toll, Vuk Branković would not participate in wars on the sultan's behalf. He did not partake in the battle on the Rovine in 1395 when the sultan was supported by both king Marko and Konstantin Dragaš. Neither did he participate in the Nikopolje battle in 1396 when Prince Lazar's son Stefan Lazarevic took part and contributed to the sultan's victory. For these reasons the sultan settled his accounts with Vuk Brankovic in 1396, which was followed by the Ottomans handing the majority of Brankovic's territories over to the Lazarević. Thus in 1396 the Lazarević family took over the Priština-based mint and continued its exploitation up until the re-ascent of the Branković family in $1402 .^{?}$

Though dependent on the sultan and under a constant threat of losing their states, each regional ruler behaved in their respective areas as if they had an absolute sovereignty. Following suit of Serbian kings and tsars they each decided independently on minting arrangements in their respective areas. Still, regional rulers did not harmonise amongst themselves their monetary policies, which resulted in a great variety of types of dinars in circulation. These differed in their appearance, weight, silver quality and the alloy structure and primarysecondary metal ratio. On the top of regional rulers' coinage, the money minted earlier, during the period of kings and tsars, was also in circulation. Money hoards dating from the period of the dissolution of Serbian empire and emerging regional rulers' autonomy represent the clearest indicator of the money minting diversity and its wide-spread character. For example, a money hoard dating back from a period 1375-1380 was found in Kičevo, in Macedonia, and amongst 350 silver dinars found therein there were dinars minted during the reign of the king and Tsar Dušan, Tsar Uroš, as well as the following feudal rulers: Jovan Oliver, king Vukašin, king Marko, Andraš, Jovan Dragaš, Andrija Gropa, Prince Lazar and Djuradj Balsić I (V. Radić, V. Ivanišević, 2001, pp. 301-303).

Vuk Brankovic died in an Ottoman prison in 1397 (M Spremić, 1994, p. 44) 


\section{An attempt to restore the monetary system}

Monetary autonomy under the sultan suzerainty in the European part of the Ottoman Empire envisaged the right to mint coinage in line either with local customs or written rules that were laid down independently by vassals. After the dissolution of Serbian Empire in 1371 local feudal lords who had now become sultan's vassals did not harmonise the monetary standards or their respective monetary policies amongst themselves. Thereby, a great variety of silver coins were in circulation. These differed in their physical looks, weight, silver quality and the structure of alloy combining a basic and an auxiliary metal. There was an attempt albeit unsuccessful to unify minting monetary standards in vassal Serbia in the first half of the $15^{\text {th }}$ century, during the epoch of Despotate. Favourable political circumstances for this to be achieved came about with the reunification of Serbian lands under the Lazarević and Branković families.

Lacking central state authority that could control money minting and feeling the pressure of duties towards the sultan, regional rulers minted money that was constantly losing weight. Apart from these political reasons, there was another valid reason of foreign economic character for the decrease in the silver dinar weight. Namely, there was a sharp silver shortage across Europe in the second half of the $14^{\text {th }}$ century and the beginning of the $15^{\text {th }}$ century. The crisis culminated after 1390 and lasted for two decades. Mints in Italian towns were closing down one after another. Only the Venetian mint was spared this money-making metal famine thanks to regular supplies from Serbian and Bosnian silver mines.

Due to growing demand for silver the price of this precious metal went up in the first decades of the $15^{\text {th }}$ century, so it became very profitable to open new silver mines in the Balkans and expand production in the old ones. Thus, monetary metal shortage crisis was overcome temporarily. By renewing silver coins minting in Italian towns conditions were created for another international exchange boost. Growing demand for monetary metal made Serbian mining and trade flourish. The production was on the increase in old mints and the same time new mints mushroomed. It was a favourable economic moment to discontinue the practice of debasements and to sort out the entire Serbian minting business. However, in order to conduct a monetary reform in the direction of minting standards unification it was necessary to achieve appropriate political conditions. First of all, a re-integration of Serbian lands was needed.

Several important political events from the beginning of the $15^{\text {th }}$ century served to enable the reunification of Serbian lands under the reign of Stefan Lazarević (1396-1427) and Vuk Branković's successors. In 1402 Vuk Branković's successors came into possession of their lands again by buying them off from Ottomans. They accepted to start paying all vassal-related duties to the sultan and to participate in his auxiliary military forces. That same year, after the defeat of the sultan Bayezid I in the battle of Angora, Prince Stefan Lazarevic 
nominally acknowledged Byzantine supreme rule and was conferred by John VII Paleologist the title of despot in Constantinople. Subsequently, he sought protection from a Hungarian king Sigismund and became his vassal. Sigismund conferred on him Belgrade and Macva region in 1403 and 1404 respectively. In 1411, Srebrnica, a great mining centre on the Drina was also conceded to Despot Stefan, and in 1421 he inherited Zeta region from Balsa III.

Money minting business was run in the mining centres such as Novo Brdo, Rudnik and Srebrnica, all of which were in the possession of Despot Stefan Lazarević. Rudnik and Novo Brdo mints operated from before, whereas minting in Srebrnica was restored in 1417 (V. Ivanišević, 2001, p. 61). Despot Stefan first continued minting silver dinars of low weight, ranging from 0.44 to 0.39 grams. However, a monetary reform was conducted between 1402 and 1407, after which he first introduced new, heavier silver coins, weighing between 1.22 and 0.82 grams, and then ordered that the old, lighter coins should be replaced. Also, Despot Stefan started minting a new type of silver coin, so called obol, which Djuradj Branković and his son Lazar would continue minting.

In want to bring some order in the money minting business Despot Stefan adopted Mining Code in 1412 whereby forgery was most severely punished. ${ }^{8}$ That far, there had been no order in money minting whatsoever, which is substantiated by difficulties to calculate value in trade due to a vast diversity of dinars in circulation. Namely, all the payments in Nemanjić Serbia were calculated in fictitious perperas only up to the $15^{\text {th }}$ century. However, ever since the beginning of that century, as various local rulers' coinage differed in quality and weight, it was difficult for the perpera to preserve its role as commonly accepted and acknowledged accounting monetary unit worth 12 silver dinars. This is why some transactions started to be calculated in litras, a silver weight measurement unit (M. Blagojević, 1981, pp. 47-62). It was a common phenomenon in the medieval ages to use monetary metal weight measurement unit as a monetary standard. Even in the times of most severe monetary crises trade transactions called for a unique measure of value, that is, of prices.

The weight of Serbian medieval litra differed from one mine to another and from one market place to the next. Litra was divided in 12 unchas; every uncha had six ascaddios and every ascaddio two halves. This system of the Serbian litra corresponded to the Roman and Byzantine litra (Č. Mijatović, 1869, p. 219). Serbian litra had varied weight, ranging from 288 to 346 grams. Written memorials mention litras of Novo Brdo, Smederevo, Srebrnica, and Rudište. For example, Novo Brdo litra weighed 337, 24 grams (M. Blagojević, 1981, p. 371). From the beginning of the $15^{\text {th }}$ century to the fall of Serbian Despotate under the Ottoman rule in 1459 litra was used as an accounting monetary unit parallel with fictitious perpera. Thus, in Serbian Despotate the payments in internal trade were

Burning at stake was replaced by thumb severing as a form of punishment for forgery ( $\mathrm{N}$. Radojčić, 1962) 
made in various types of silver dinars whereas perpera and litra were used as accounting monetary units. Stefan Lazarević's Mining Code from 1412 bears witness to this. For example, Article 26 stipulates that membership in a mining association costs "one perpera", whilst Article 40 has it that officers in charge of granting concessions for mining exploitation were to be paid "two litras of dinars" (B. Marković, 1985, pp. 17-19). In economic sense, payments expressed in litras meant a retrograde process. Whilst fictitious perpera was used as 12-dinars worth unit of account, silver dinars that were used for paying would be physically counted. ${ }^{9}$ Counting resulted from a need to technically facilitate and speed up payments expressed in money the quality of which was not doubted. However, when litra was used, as silver weight unit of account, then silver dinars were physically weighed. This process of going back to weighing money was a sure sign of losing trust in dinar quality and ruler's insignia.

Between 1402 and 1429, during the reign of Vuk's successor Djuradj Branković (1402-1456), Serbian territories spread from Sjenica in the north, Trepča and Prišitna in the east, Prizren in the south and Plav in the west. These lands were constantly under Ottoman attacks as they were situated on the road towards important mining and trade centres that Ottomans strove to conquer. For example, in 1415 the Ottomans captured some Branković lands and subsequently Bosnia, forcing it to pay tribute. They did the same in 1425 where they "conquered Serbs" in master Djuradj's lands (M. Spremić, 1994, p. 90). This time their target was Novo Brdo. Sultan Murad II (1421-1444, 1445-1451) reached the town's walls but never succeeded in taking it. In 1427, the moment when Despot Stefan Lazarević died Murad was in front of the town walls. The Novo Brdo siege lasted for 48 days. Sultan used heavy artillery. He lifted the siege when the winter started. Such unfavourable political conditions had a negative effect on production in all mints held by Djuradj Branković (V. Ivanišević, 2001, p. 176).

In 1427 Serbia was devastated and awash with Ottomans. There was a constant danger of new attacks, primarily with a view to taking some other important mining or trade centres. In order to save Serbia, after the death of Despot Stefan Lazarević, Master Djuradj became Hungarian vassal. Namely, with his health deteriorating gravely in 1426, at a state council in Srebrnica Despot Stefan had proclaimed Djuradj the Serbian throne heir. But in order to become a new Serbian ruler Djuradj had to be recognised abroad too. He was initiated in the Hungarian baron order by the contract of Trata in May 1426, and Hungarian king Sigmund made it clear that Djuradj, once he became the ruler, had to hand over Belgrade, Golubac and Mačva county back to Hungarians. When Djuradj became Hungarian vassal in 1427 he gave them back Belgrade, but not the surro-

$9 \quad$ The payment system based on counting coins instead of weighing monetary metal was first introduced in the $7^{\text {th }}$ century BC in Lydia, Asia Minor, as a sign of trust in traders who had started imprinting their insignia on pieces of electrum, gold and silver alloy, and then later such once stamped pieces would not be weighed any more. Shortly afterwards, Lydian rulers took the practice over from traders (V. Meichsner, 1981, p. 12)

Vol. 11, No 4, 2014: 129-144 
undings. Thus the mine of Rudista near the Mountain Avala remained in Serbian possession. This was extremely important for Serbian monetary system as Djuradj Branković soon founded a new money mint in Rudište.

After the death of Despot Stefan Lazarević in 1427 and Master Djuradj Branković succeeding the throne, the Lazarevićs' and Brankovićs' countries were finally unified. Djuradj Branković ruled as a twofold vassal and his territory ranged from the Danube in the north and the Adriatic in the south. His country was squeezed in between Hungary and the Ottoman Empire and under constant threat from the both suzerains' conquering ambitions. Djuradj was conferred the title of despot in 1429 by the Byzantine Tsar John Paleologist VII (M. Spremić, 1994, p. 136). Despot Djuradj will continue ruling the vassal Serbia till his death in 1456. After acceding to Serbian throne he considerably increased coinage minting and continued the process of monetary system restoration, as started by Despot Stefan Lazarevic.

In 1430, a money mint started operating in Smederevo following the completion of building the town in the capacity of Serbian capital. Around 1435 Djuradj Branković conducted a monetary reform. The reform strengthened the silver dinar value and marking of the coins was started. It was stipulated that 16 old dinars should be exchanged for 10 new dinars (M. Dinić, 1955, p. 67), as their weight was now increased. Based on some numismatic findings it has been established that average weight of two different types of the new dinars minted at the time at the Novo Brdo mint stood between 1.00 gram and 1.05 grams (V. Ivanišević, V. Radić, 2004, p.234). Furthermore, new silver dinars had the new capital mint Smederevo marks on it, as well as the marks of the mints in Rudnik, Rudište and Novo Brdo (V. Ivanišević, 2001, p. 181).

Given incessant Ottoman attacks that brought either temporary or permanent loss of territories, political and economic circumstances in Serbian Despotate constantly deteriorated. Despot Djuradj Brankovic tried to preserve Serbian autonomy by means of fulfilling his vassal obligations on two sides, towards Ottomans and Hungarians. He also tried to act as a mediator between the two suzerains to remain at peace for as long as possible. The monetary autonomy character and money value itself depended increasingly less on reformist moves and more and more on political circumstances marked by the intentions of Murad II to conquer Serbia once and for ever. When the Ottomans annexed the south of Serbia to the Empire (with strongholds in Niš, Stalać, Bela Palanka and Pirot) and put it under sultan's direct rule in 1433, Djuradj's monetary reform effects were exhausted. Territorially, the Despot's monetary autonomy had shrunk significantly and the money was speedily being debased. At the time, Djuradj's silver dinars were losing their value not only due to constant decreasing of their weight but also through the monetary metal quality erosion. For example, Despot Djuradj Branković's dinars minted at the time in Srebrnica had a quality rate 
of 0.666 , which means that one third of every litra of the monetary metal was copper (V. Ivanišević, 2001, p. 47).

After the irreversible loss of territories in the south of Serbia, the rest of the Despotate's existence, which also meant the rest of Serbian monetary autonomy, depended exclusively on the sultan's whim. Murad II was led by the assessment on how much vassal duties had already exhausted the Despotate and what would pay off to him more: to keep it in the vassal position or to finally conquer it altogether. After he conquered the south of Serbia his advisors guided him towards finishing the process and annexing the rest of Djuradj's increasingly smaller state but he answered that "in this way, he would (author's remark: still) get more cavalry men than if the country were in his hands entirely" (M. Spremić, 1994, p. 98).

What brought a definitive disaster to Djuradj's state was a Hungarian war campaign via Serbia against the sultan's armed forces in 1437. Driving away the Hungarian army within the following two years, the Ottomans would conquer almost the whole of Serbia. When at the end of spring in 1439, after almost three months of siege, the sultan's army finally took Smederevo, the Serbian Despotate fell into the Ottomans' hands for the first time. That same year, all Djuradj's mints stopped working, except for the one in Novo Brdo. After months of siege, Novo Brdo surrendered too in 1441 when The Ottomans stormed it.

\section{The loss of monetary autonomy}

When the capital Smederevo fell into the Ottoman hands for the first time in 1439 Serbia temporarily lost its internal autonomy, to regain it only in 1444 . On the other hand, when the same destiny befell Novo Brdo in 1441 Serbia lost its monetary autonomy likewise, that is, minting of silver dinars was discontinued, for the first time since 1270s. Djuradj Branković no longer had his capital city, mines or mints so he deposited his treasure in Dubrovnik and took refuge in Hungary. The only mint in Serbia that continued operating under the Ottoman rule was the one in Novo Brdo. Ottoman imperial minting supervisor, so called emin, was appointed there in 1441 and he organised minting of silver akçe coins that carried the name of Sultan Murad II and markings of a new Ottoman mint Novar.(S. Srećković, 1987, pp. 53-55).

Following several defeats in a row sustained by the Ottoman army in clashes with the Christian forces in 1442 and 1443 Murad II agreed to return to Despot Djuradj his state in 1444. Djuradj came back to Serbia and made a peace deal with Murad II whereby Djuradj promised to fulfil all vassal duties within the following ten years. In return, sultan re-established all the autonomous rights Djuradj enjoyed before, including the monetary autonomy. Despot Djuradj regained the control of some important mining centres and towns where mints were situated, so now, after four years, he was once again in a position to continue 
national money minting. Serbian coin minting was renewed exclusively in the mints inland as in 1443 Venetians had conquered the entire coast, from Kotor to Bojana. Thus, after several centuries, Serbian state had lost exit to the sea, whereby Serbian money minting business lost important minting centres, such as Kotor and Ulcinj.

Following regaining of the state, Despot Djuradj renewed coin minting in Novo Brdo, as well as in Smederevo and Rudista. For the first time after four years minting of the Ottoman akçe in Novo Brdo stopped. The allegation that Despot Djuradj, apart from silver dinars, also had Ottoman akçe minted is unfounded (S. Dimitrijević, 1997, p. 20). It had never happened in the European part of the Ottoman Empire that sultan conceded to any vassal a part of his monetary sovereignty. The sultan's vassals' monetary autonomy in this part of the Empire had always encompassed exclusively their right to mint their own coins, never Ottoman ones (S. Pamuk, 2000, pp. 88-95).

Between 1444 and 1448 the minting centre in Srebrnica was alternately in the hands of the Bosnian king Tomaš or a part of Djuradj's state. Regional changes in autonomy holders under the Ottoman suzerainty affected coin minting in the Srebrnica mint. Between 1446 and 1448 when the Bosnian king temporarily ruled Srebrnica Despot Djuradj minted coins together with him. However, between 1448 and 1458, when Srebrnica was a part of Serbian Despotate throughout, only Serbian coins were minted there.

Though Djuradj Branković regained his right to mint his coins in 1444, he had neither political nor economic power anymore to renew Serbian monetary autonomy in the full sense of the phrase. At the time, one of the crucial characteristics of the monetary situation in Serbia was great presence of Ottoman coinage in circulation. Ottoman silver akçe appeared in circulation in Serbia after the Battle of Kosovo, during the reign of sultan Bayezid I, and during the rule of Murad II akçe coins were in parallel use with Despot Djuradj Brankovićs dinars. This could be accounted for both politically and economically. The Ottomans finally introduced their own monetary system in Serbia following the definitive conquest of the south of Serbia in the 1430s. However, Ottoman akçe coins soon appeared in circulation also in those regions regained by Djuradj in 1444 as Djuradj's mints had no capacity to satisfy the demand for specie. This is corroborated by the enormous presence of Ottoman copper mangirs in circulation that served for everyday small transaction payments (V. Ivanišević, V. Radić, 2004, pp. 234-236).

As soon as after sultan Murad II died in 1451, Mehmed II (1444-1445, 14511481) who acceded to the Ottoman Empire throne decided to subject the remaining Christian Balkan states. The fall of Constantinople in 1453 cleared his path towards the fulfilment of this intention. After 10 relatively peaceful years, in July 1454 Ottoman army attacked Serbia. The consequences of Mehmed's wars were fatal for Djuradj's state. The country was desolated, citizens scattered and redu- 
ced, there were no more conditions to conduct peaceful trade whatsoever. For all these reasons, there can be no more talk about Serbian monetary autonomy in the period between Mehmed's conquests in 1454 until the final fall of Serbian Despotate in 1459 . Only sporadic minting of silver dinars was in place in this period.

On the $1^{\text {st }}$ of June in 1455, after a two-month siege, the Ottomans conquered Novo Brdo. The second fall of Novo Brdo marked the end of Serbian medieval minting at this that far most important Serbian mint of the time. The Ottomans then organised silver akçe minting anew, and now these were the coins of Mehmed II (S. Srećković, 1987, p. 53) By means of peace accord from 1455 between Mehmed II and Djuradj Branković, Serbian Despotate was confined to its northern part: it covered regions between the rivers Western Morava and The Danube. Its political and economic life was predominantly linked to the capital Smederevo where there was a mint operating until the capital's final fall into the Ottoman hands. At this mint Despot Djuradj had silver dinars and silver obols minted until his death in 1456. His son Despot Lazar (1456-1458) continued minting coinage. After the assassination of Despot Lazar in January 1458 for a short period of time his blind brother Despot Stefan ruled in Smederevo. He had his own coins minted so that "a spark of the state spiritual life was maintained under the last Serbian ruler" (M. Spremić, 1994, p. 525). Serbian last medieval dinars and obols minted in Smederevo weighed 0.99 and 0.22 grams respectively (M. Ivanišević, 2001, p. 193, 194). When Smederevo fell in the Ottoman hands in 1459 Serbia lost its monetary autonomy that was to be renewed as late as in the $19^{\text {th }}$ century.

\section{Conclusion}

The right to mint coinage was one of grand ruling rights in the middle ages. Thus, this right was centralized in medieval Serbian State as long as the rulers were strong enough to oppose to the interests of local feudal landlords and ottoman suzerains. Disintegration of the monetary system of medieval Serbia started in 1355, only after the unexpected death of Tsar Dušan and lasted almost a century, to 1349, until Serbian Despotate was concurred by Ottomans. Thus the process of monetary system disintegration coincided with the dissolution of the State. During that long period, Serbian silver currency dinar had experienced alternatively debasements and restorations. It had been minted by local feudal landlords who usurped the ruling right to mint coinage as well as by rulers from Lazarević and Branković families who tried albeit unsuccessfully to restore the unified monetary system. The economy suffered continuously from instability. This can be proved best with the fact that this period was characterized by phenomenon of retrograde custom of frequent turning backwards to using weighted silver instead of silver coinage as unit of account in everyday economic transactions. 


\section{Literature}

- Blagojević, M. (1981) Osnove privrednog razvitka (Foundations of Economic Development), Istorija srpskog naroda, Srpska književna zadruga, Belgrade

- Blagojević, M. (1981) „Peprera i litra u doba kneza Lazara” “"Perpera and Litra in the Time of Prince Lazar"), Istorijski časopis, 1-2, 1981, pp. 47-62

- Gnjatović, D (1998). Dobri i zli dinari, Funkcije novca i novčani isistem srednjovekovne Srbije (Good and Evil Dinars, Monetary Functions and Monetary System of Medieval Serbia), Yugoslav Survey, Belgrade

- Gnjatović, D. (2000) „Death Penalty for Clandestine Money Minting in Tsar Dusan's Code of Laws", Science, security, police, Vol. V, No 2, 2000, pp. 107-128

- Dimitrijević, S. (1959) „Hronologija Dušanovog carskog novca” (“Chronology of Dušan's Imperial Money”), Istoriski časopis, Serbian academy of sciences, No 9-10, pp. 113-138

- Dimitrijević, S. (1997) Serbian Medieval Money, Serbian academy of arts and sciences, Belgrade

- Dinić, M. (1955) Za istoriju rudarstva u srednjovekovnoj Srbiji i Bosni I (History of Mining in Medieval Serbia and Bosnia I), Serbian academy of sciences, Belgrade

- Ivanišević, V. (2001) Serbian Medieval Coinage, Stubovi kultre, Belgrade

- Ivanišević, V. Radić, V. (2004) „Serbian Medieval Mint in Novo Brdo”, Novo Brdo, Republički zavod za zastitu spomenika kulture, Belgrade

- Inaldzik, H (1974) Osmansko carstvo, klasicno doba 1300-1600 (Ottoman Empire, Classical era 1300-1600), Srpska književna zadruga, Belgrade

- Marković, B. (1985) Despot Stefan Lazarevic's Mining Law, Memorial CXXVI, Serbian academy of arts and sciences, Belgrade

- Maxim, M. (1998) „In the Right to Strike Currency of the Reigning Princes of Moldavia and Wallachia during the Period of Ottoman Suzerainty“; The Journal of Ottoman Studies, No 18, 1998, pp. 69-88

- Meichsner, V. (1981) Osnovi monetarnog prava (Principles of Monetary Law), Informator, Zagreb

- Mijatovic Č. (1869) „Stara srpska litra” (“Old Serbian litra“), Glasnik srpskog učenog drustva, XV, Belgrade

- Novakovic, S. (1933) Srbi i Turci u 14. I 15. veku (Serbs and Turks in the $14^{\text {th }}$ and $15^{\text {th }}$ centuries), Prosveta A.D., Belgrade

- Novakovic, S. (1898) Zakonik Stefana Dušana cara srpskog 1349 i 1354(The Code of Serbian Tsar Stefan Dusan from 1349 and 1354), Državna stamparija Kraljevine Srbije, Belgrade

- Pamuk, S. (2000) A Monetary History of the Ottoman Empire, Cambridge University Press, Cambridge 
- Radić, V., Ivanišević, V. (2001) „Serbian Medieval Coin Hoards in the National Museum Collection in Belgrade", National museum journal, XVII-1, Belgrade

- Radojčić, N. (1962) Despot Stefan Lazarevićs Mining Law, Serbian academy of arts and sciences, Belgrade

- Radonić, J. (1914) „O despotu Jovanu Oliveru” (“About Despot John Oliver"), Glas Srpske kraljevske akademije, XCIV, 1914, pp. 74-108

- Spremić, M. (1970),Turski tributari u 14. i 15. veku” (Turkish Tributaries in the $14^{\text {th }}$ and $15^{\text {th }}$ Centuries"), Istorijski glasnik, No 1-2, 1970, pp. 9-59

- Spremić, M. (1994) Despot Djuradj Brankovic i njegovo doba (Despot Djuradj Brankovic and his Epoch), Serbian literary association, Belgrade, 1994

- Srećković, S. (1987) Ottoman Coins minted on the Yugoslav Territory, Belgrade

- Stojakovic, S. (2006) Despot Stefan Lazarević, Serbian numismatic society, Belgrade 


\title{
Dr Dragana Gnjatović,
}

Redovni profesor Fakulteta za hotelijerstvo i turizam u Vrnjačkoj Banji

Univerziteta u Kragujevcu

\section{DEZINTEGRACIJA MONETARNOG SISTEMA SREDNJOVEKOVNE SRBIJE}

\begin{abstract}
S a ž e t a k
Predmet ovog rada je analiza procesa postepene dezintegracije monetarnog sistema srednjovekovne Srbije tokom druge polovine 14. i prve polovine 15. veka. Ovaj period karakteriše pojava čestih uzurpacija vladarskog prava kovanja novca od strane lokalnih feudalnih gospodara i pokušaja vladara iz porodica Lazarević i Branković da restauriraju unificirani monetarni sistem. Česte pojave smanjivanja i povećavanja vrednosti srebrnog novca uzrokovale su ekonomsku nestabilnost i iniciale povratak na retrogradni običaj koriščenja merenog srebra umesto kovanog novca kao mere vrednosti u sistemu robne konvertibilnosti. Cilj ovog rada je da se objasne razlozi ovakvih pojava. Primenjena je kvalitativna, istorijsko empirijska analiza u kojoj se posmatraju nosioci prava kovanja novca i njihove odluke o smanjivanju i povećavanju vrednosti novca. Analiza je pokazala da je postepena dezintegracija monetarnog sistema srednjovekovne Srbije, koja je trajala sve do pada Srpske Despotovine bila posledica političke nestabilnosti prouzrokovane raspadom srpske carevine i finansijskim iscrpljivanjem Srbije od strane osmanlijskih sizerena.
\end{abstract}

Ključne reči: pravo kovanja novca, robna konvertibilnost, smanjivanje I povećavanje vrednosti srebrnog dinara, Srpska Despotovina, osmansko sizerenstvo 